\title{
Rehabilitation and retrofitting of existing structures through external bonding of thin carbon fibre sheets
}

\section{URS MEIER}

Director of EMPA

\section{INTRODUCTION}

According to a study published in 1989, in the OECD countries the average annual expense for the maintenance of bridges amounts to $2.1 \%$ of their initial cost; this results in annual repair costs of about $\$ 3600$ million. These considerations illustrate the great importance of effective renovation methods for existing structures. Thus, poststrengthening structures by the bonding of steel plates or fibre reinforced composite laminates achieves great significance. Steel plates have some disadvantages. They are not corrosion resistant and they are heavy. Therefore handling on site is difficult. On the other hand, highstrength fibre composite laminates are very light, relatively thin and can be delivered to the construction site in rolls, in lengths of up to $300 \mathrm{~m}$ or more. Compared with steel plates their application is greatly simplified. Table 1 shows which fibre is most suitable for such applications.

\section{DESIGN CONSIDERATIONS FOR UNPRETENSIONED BONDED CFRP LAMINATES}

In 1987 it was shown that post-strengthening with carbon fibre reinforced plastics (CFRP) is possible [1]. As a result of comprehensive investigations at the EMPA, Kaiser [2] came to the following conclusions.

Post-strengthening of structural components with CFRP laminates may be calculated in flexure analogously to conventional reinforced concrete.

Table I Rating of the fibre types

\begin{tabular}{|c|c|c|c|c|}
\hline \multirow[t]{2}{*}{ Criterion } & \multirow{2}{*}{$\begin{array}{l}\text { Weighting } \\
\text { factor } \\
(1 \ldots 3)\end{array}$} & \multicolumn{3}{|c|}{$\begin{array}{l}\text { Weighted rating for } \\
\text { laminates with fibers of }\end{array}$} \\
\hline & & carbon & aramid & E-glass \\
\hline Tensile strength & 3 & 9 & 9 & 9 \\
\hline Compressive strength & 2 & 6 & 0 & 4 \\
\hline Young's modulus & 3 & 9 & 6 & 3 \\
\hline Long term behaviour & 3 & 9 & 6 & 3 \\
\hline Fatigue behaviour & 2 & 6 & 4 & 2 \\
\hline Bulk density & 2 & 4 & 6 & 2 \\
\hline Alkaline resistance & 2 & 6 & 4 & 0 \\
\hline Price & 3 & 6 & 6 & 9 \\
\hline Total points & & 55 & 41 & 32 \\
\hline Ranking & & 1 & 2 & 3 \\
\hline
\end{tabular}

a Rating: very $\operatorname{good}=3, \quad \operatorname{good}=2, \quad$ adequate $=1$ and inadequate $=0$ points.
Special attention must be paid to the formation of shear cracks in the concrete. Such shear cracks lead to an offset on the strengthened surface. This generally causes a peeling-off of the strengthening laminate. Thus, shear crack formation is a design criterion.

Flexure cracks are spanned by the laminate and do not influence the carrying capacity.

The carrying capacity may be predicted accurately in advance.

The calculation model for the anchoring of the laminates agrees with experiments over a wide range. For short anchoring lengths the model underestimates the carrying capacity of thick laminates and for thin laminates overestimates it.

Bonded CFRP laminates have a very positive influence on crack development of a reinforced concrete beam. The cracks are more finely distributed and the sum of the crack widths is greatly reduced. Even after exceeding the yield point of the inner reinforcement the crack growth remains under control up to failure thanks to the elastic CFRP laminate.

CFRP laminates exhibit excellent fatigue behaviour. Through the bonding of the CFRP laminate the inner reinforcement is relieved. Tests with very high vibration amplitudes yielded excellent results $[2,3]$ over more than 10 million load cycles.

\section{DESIGN CONSIDERATIONS FOR PRETENSIONED, BONDED CFRP LAMINATES}

In EMPA Report No. 224 [3] Deuring shows the potentials of pretensioned laminates. Following the pretreatment of the laminate and concrete surfaces described above, the CFRP laminate is tensioned to $1000 \mathrm{MPa}$ using a special tensioning device. The adhesive is applied before pressing the tensioned laminate to the structure. After hardening of the epoxy resin the force-transfer zones at the laminate ends are provided with patented CFRP pressure plates in order to transfer the large forces of the laminate into the concrete. As a result of a pressing force perpendicular to the laminate surface the shear strength of the concrete is increased; if horizontal microcracks occur, the laminate remains anchored successfully to the structure owing to the effective interlocking of the laminate. Finally, the external tension is lowered and the structure is not only strengthened through a CFRP laminate, but also it is prestressed. In this way, even existing cracks can be closed. Deuring [3] comes to the following conclusions. 
The calculation procedure predicts closely the load behaviour of a structure post-strengthened with a pretensioned CFRP laminate.

Since the CFRP laminate has no plastic deformation reserve the highest flexural resistance of a strengthened section is reached when laminate failure occurs simultaneously with the yield of the steel and before the concrete fails.

The type of failure is strongly influenced by the laminate cross-section and the tensioning force.

Tension and deformation calculations may be carried out with conventional methods. Test results on realistic beams confirm the validity of the classical assumptions.

Pretensioning reduces the danger of peeling off, mentioned above for non-pretensioned laminates.

The total sum of the crack widths is influenced even more favourably than with non-pretensioned laminates.

The excellent fatigue behaviour exceeds all expectations.

\section{APPLICATIONS IN BRIDGE AND BUILDING CONSTRUCTION}

Since 1991 there have been many applications of this new technique in Switzerland. In 1991 the first bridge, the Ibach Bridge near Lucerne [4], in 1992 the covered wooden bridge in Sins [4], and the City Hall in Gossau, St. Gall [4], were renovated with this method. In 1993 there were already more than 30 new cases. Currently, there is every week at least one new application of the CFRP sheet bonding technique in Switzerland.

\section{OUTLOOK}

Based on the research and development work at EMPA the application of CFRP laminates is already routine for several companies in Switzerland. In the USA, where the market potential is actually the greatest, things have not yet advanced quite so far. Nevertheless, the American government is making great efforts, above all in the Defense Conversion Program, to promote high performance fibre composites, particularly carbon fibres for civil engineering applications. Within the framework of the 'Advanced Materials Bridge Initiative' [5] the Federal Government is investing $\$ 200$ million to stimulate this program. On the one hand, this involves rehabilitation work as described in this paper and on the other hand futuristic projects as already sketched out by Meier [6]. In the author's opinion fibre composites have excellent chances in specific civil engineering applications as described here. However, even in the future they will not replace classical materials such as steel, concrete and wood, but rather supplement them as called for.

\section{REFERENCES}

1. Meier, U., 'Brückensanierungen mit HochleistungsFaserverbundwerkstoffen', Mater. Technik 15 (1987) $125-128$.

2. Kaiser, H. P., 'Bewehren von Stahlbeton mit kohlenstoffaserverstärkten Epoxidharzen, Dissertation, ETH No. 8918 (Eidgenössische Technische Hochschule, Zurich, 1989).

3. Deuring, M., 'Verstärken von Stahlbeton mit gespannten Faserverbundwerkstoffen', EMPA-Bericht No. 224 (Eidgenössische Materialprüfungs- und Forschungsanstalt, EMPA, Dübendorf, 1993).

4. Meier, U., Deuring, M., Meier, H. and Schwegler, G., 'Strengthening of structures with advanced composites', in 'Alternative Materials for the Reinforcement and Prestressing of Concrete', edited by John L. Clarke (Chapman \& Hall, 1993) pp. 153-171.

5. National Technology Policy: Recommendations \& Initiatives, Adv. Composites (Jan./Feb. 1993) p. 15.

6. Meier, U., 'Proposal for a carbon fibre reinforced composite bridge across the Strait of Gibraltar at its narrowest site', Proc. Instn Mech. Engrs 201 (B2) (1987) 73-78.

\section{Fibre reinforced plastic splices for joints in timber structures}

\author{
A. ULRICH MEIERHOFER \\ EMPA Department Wood
}

\section{INNOVATIONS FOR TIMBER STRUCTURES}

Fibre reinforced plastic (FRP), where applied at all in timber construction, has been merely for repair and secondary functions. Recently, after an extended period of development and research, a new system has been introduced in the US market which should provide for the economical reinforcement of glulam beams with FRP [1]. The application of FRPs to connections between structural timber parts is the goal of a research and development project of the EMPA Wood Department.
For timber structures, the design of the joints plays a decisive role and poses a challenge for innovative trials, especially regarding the transfer of tensile forces.

\section{TENSILE JOINT}

Preliminary tensile tests with small FRP-spliced specimens were performed to determine the influence of various parameters like type of resin, thickness of glueline, or length of splice of FRP-lamination and to gather experience with the workability and the adhesion of the 